\title{
RESERVOIR EFFECT OF THE SOUTHERN AND SOUTHEASTERN BRAZILIAN COAST
}

\author{
Rodolfo J Angulo ${ }^{1,2} \cdot$ Maria C de Souza $^{1} \bullet$ Paula J Reimer $^{3} \bullet$ Sueli K Sasaoka ${ }^{4}$ \\ ABSTRACT. A regional marine reservoir correction $(\triangle \mathrm{R})$ of $33 \pm 24{ }^{14} \mathrm{C}$ yr for southern Brazil was obtained from 6 marine \\ shell samples collected in the states of Santa Catarina and Paraná. This work also presents a $\Delta \mathrm{R}$ estimation of $8 \pm 17{ }^{14} \mathrm{C}$ yr \\ for the southern and southeastern Brazilian coast from the states of Rio de Janeiro to Santa Catarina, obtained by including 7 \\ ages published in previous works. The high variability of $R$ in modern and Holocene samples from the Brazilian coast is also \\ discussed.
}

\section{INTRODUCTION}

The Holocene relative sea-level variation curves of the Brazilian coast (e.g. Suguio et al. 1985; Angulo and Lessa 1997) were constructed using conventional radiocarbon ages that are $\delta^{13} \mathrm{C}$ corrected (Stuiver and Polach 1977). The paleosea-level indicators used to construct those curves include remains of continental, marine, and estuarine organisms. To improve the temporal accuracy of these curves, the conventional ${ }^{14} \mathrm{C}$ ages should be converted into calibrated age ranges, which account for the temporal ${ }^{14} \mathrm{C}$ atmospheric variation (Stuiver and Braziunas 1993). However, to convert conventional ${ }^{14} \mathrm{C}$ ages of marine samples into calibrated ages, it is necessary to correct for the reservoir effect. Stuiver and Braziunas (1993) calculate a model marine reservoir age $(R)$ of $360{ }^{14} \mathrm{C}$ yr for surficial Southern Hemisphere marine waters in AD 1830 relative to the Southern Hemisphere atmosphere. However, there are significant regional differences $(\Delta \mathrm{R})$. These differences can be as large as $885 \pm 45{ }^{14} \mathrm{C}$ yr in the Ross Sea, Antarctic Ocean (Stuiver et al. 1986). Thus, to convert conventional marine ${ }^{14} \mathrm{C}$ ages into calibrated ages, it is necessary to know the regional $\Delta R$.

Until 2001, there were no published pre-nuclear testing marine reservoir data for the Brazilian coastal surficial marine waters. Nadal de Masi (2001) published the first measurements of $R$ for the Santa Catarina coast, southern Brazil. He presented $8{ }^{14} \mathrm{C}$ dates of marine shells from the northern coast of Ilha de Santa Catarina (Figure 1). One sample collected in 1945 exhibited ${ }^{14} \mathrm{C}$ activity higher than modern. The other ${ }^{14} \mathrm{C}$ ages were between $720 \pm 40$ to $390 \pm 30 \mathrm{BP}$ (Table 1). Eastoe et al. (2002) published new $R$ values for the SW Atlantic coast. They dated charcoal-shell pair samples of a shell mound named Jabuticabeira. They also dated shells collected alive in 2000 on the Santa Catarina coast and shells from Museu Nacional do Brasil, collected in 1939 and 1944 on the Rio de Janeiro coast (Table 1). The Nadal de Masi (2001) and Eastoe et al. (2002) results of modern and shell mound samples show large variations of $R$. In particular, 6 shell samples of the same species (Tellina lineata), collected in the same year (1942) in the same place (Ponta das Canas, Santa Catarina), exhibited $R$ values from $540 \pm 46$ to $204 \pm 44{ }^{14} \mathrm{C}$ BP (Figure 1, Table 1). To determine the regional $R$, Nadal de Masi (2001) excluded the sample supposedly collected in 1945 with ${ }^{14} \mathrm{C}$ activity higher than modern $(>100 \mathrm{pMC})$. Although the cause of the high ${ }^{14} \mathrm{C}$ activity is unknown, this sample may have been collected after nuclear weapons testing and thus mislabeled. He also excluded 2 samples collected in 1942 that dated to $720 \pm 40$ and $690 \pm 40$ BP because these ages were statistically different from the others. He calculated a mean age of $460{ }^{14} \mathrm{C}$ yr using only the 5 samples with statistically similar ages. On the other hand, Eastoe et al. (2002) concluded that $R$ is

\footnotetext{
${ }^{1}$ Departamento de Geologia, Universidade Federal do Paraná, Cx. P. 19001, Curitiba-PR 81531-970, Brazil.

${ }^{2}$ Corresponding author. Email: angulo@ufpr.br.

${ }^{3}$ Center for Accelerator Mass Spectrometry, Lawrence Livermore National Laboratory, Livermore, California 94550, USA. Now at School of Archaeology and Palaeoecology, Queen's University Belfast, Belfast BT7 1NN, United Kingdom.

${ }^{4}$ Museu de História Natural Capão da Imbuia, Rua Benedito Conceição 4407, Curitiba-PR 82810-080, Brazil.
} 
variable through time. They also determined that the marine samples ages could only be corrected after knowing the temporal variability of $R$. According to Eastoe et al. (2002), samples between 2500 and 1595 BP and some modern samples of Santa Catarina can be corrected by an $R$ of $220 \pm 20{ }^{14} \mathrm{C}$ yr. Other modern samples from Santa Catarina and Rio de Janeiro indicated an $R$ of $510 \pm 10{ }^{14} \mathrm{C}$ yr. According to the same authors, the age differences of the samples can be attributed to short-term (seasonal to decadal) $R$ variations on coastal waters caused by upwelling.

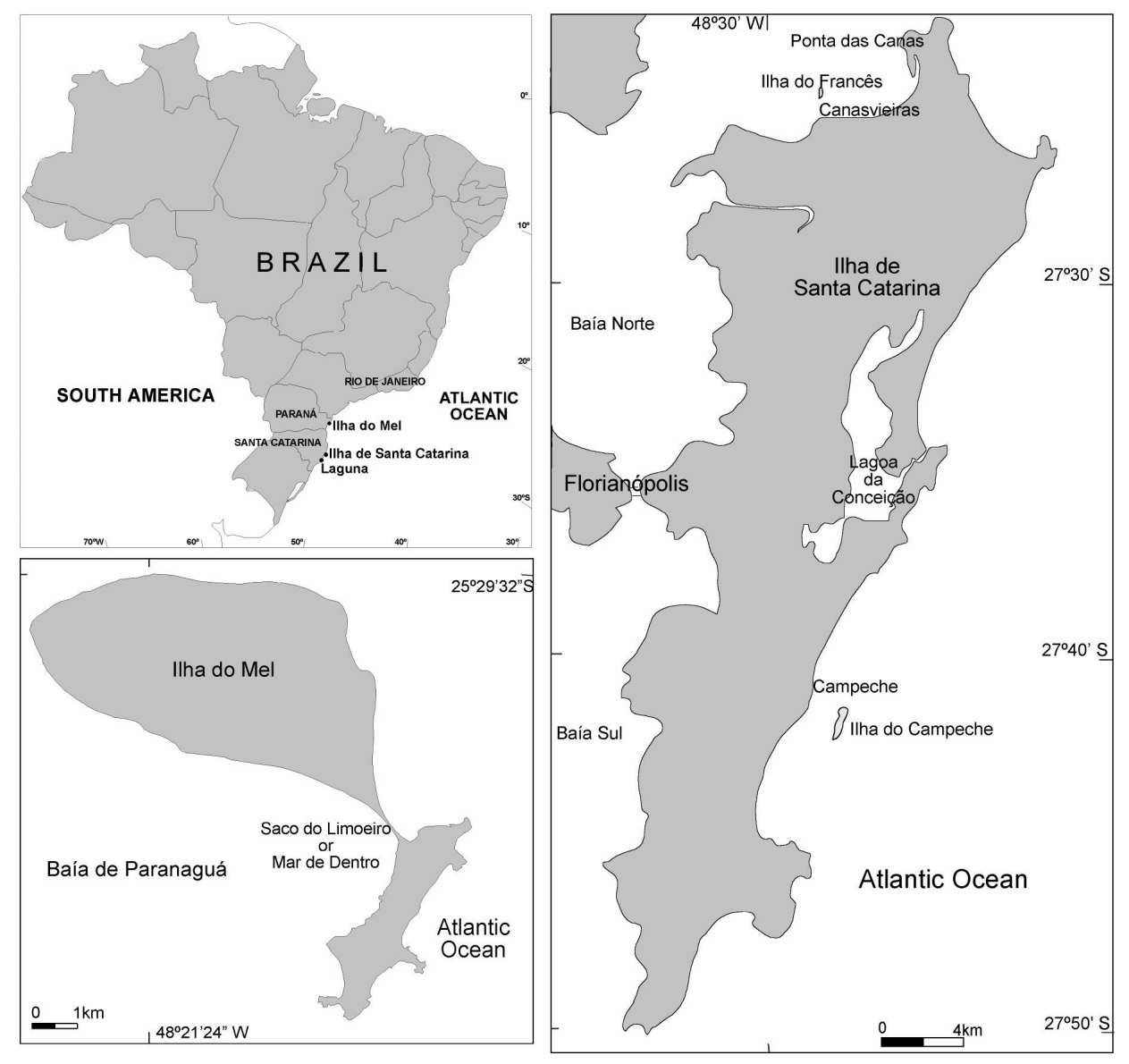

Figure 1 Location of sample sites in Paraná and Santa Catarina states, southern Brazil

Using only the marine samples collected between 1939 and 1944 published by Nadal de Masi (2001) and Eastoe et al. (2002), Reimer and Reimer (2001) calculated a mean $\Delta \mathrm{R}$ for the SW Atlantic coast of $89 \pm 46{ }^{14} \mathrm{C}$ yr.

\section{METHODS}

This paper reports on research, with the aim of refining the $\Delta \mathrm{R}$ value of southern Brazilian surficial coastal marine waters. Shell samples were obtained from the Museu de História Natural Capão da Imbuia collection. Samples chosen were collected before nuclear explosions in the atmosphere and were without abrasion evidence. Two samples of pelecypod (Callista maculata and Raeta plicatella) and 3 samples of gastropod (Janthina janthina, Pugilina morio, and Nassarius vibex), col- 


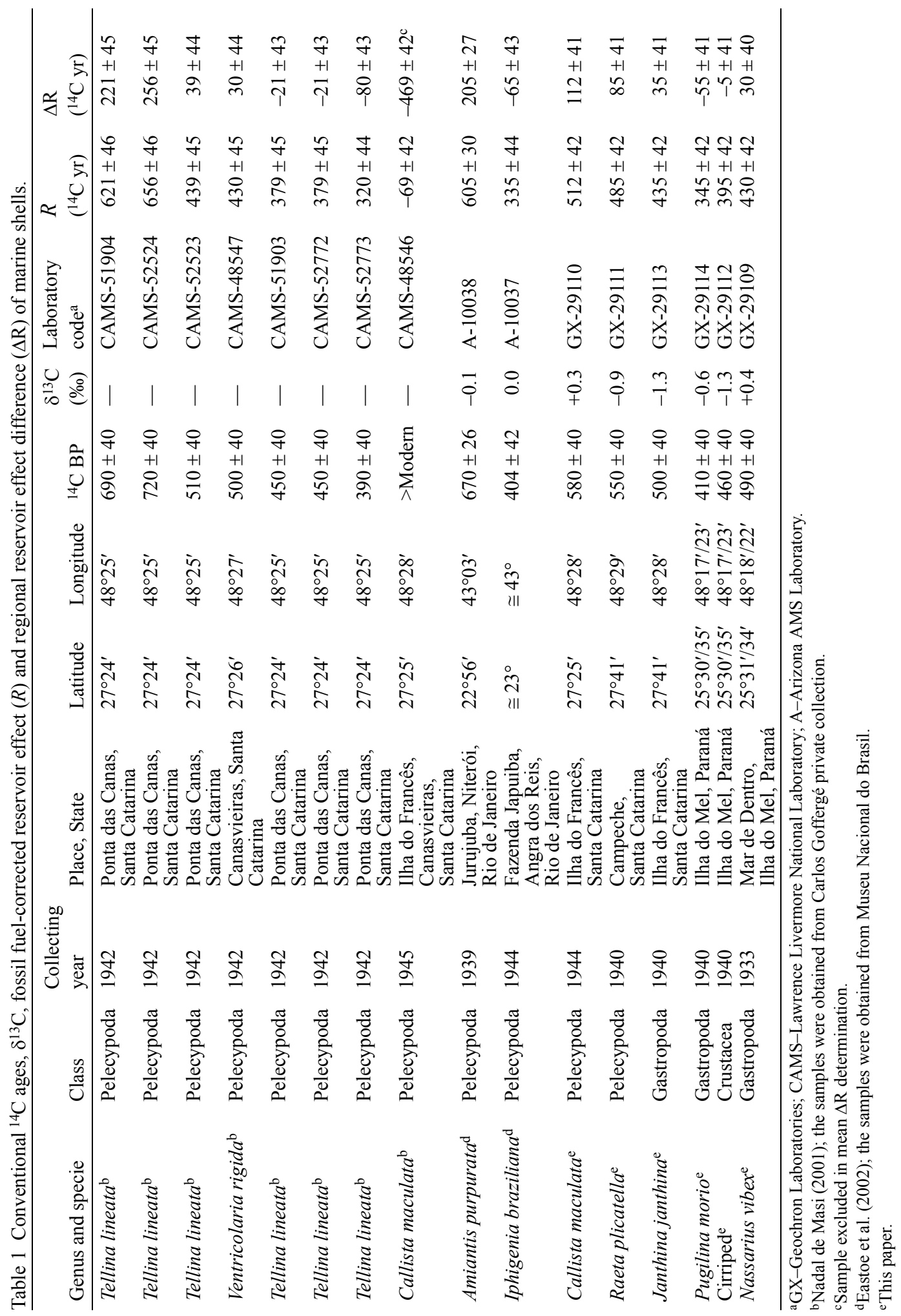


lected between 1933 and 1944 on the coast of Paraná and Santa Catarina states, were dated. A sample of cirriped fixed on a $P$. morio shell was also dated. The samples were dated by accelerator mass spectrometry (AMS) in the Geochron Laboratories. The $R$ and $\Delta \mathrm{R}$ were calculated with an Excel macro developed for the Marine Radiocarbon Reservoir Correction database (Reimer and Reimer 2001) using the Southern Hemisphere atmospheric data of Hogg et al. (2002) and the global marine calibration data set Marine98 (Stuiver et al. 1998). The reported uncertainties are the larger of the standard deviation in the mean and the square root of the variance. $R$ was corrected for differential fossil fuel additions to the atmosphere and ocean mixed layer since AD 1850. This work also aims to discuss the high variability of $R$ data given by modern and Holocene samples of Brazilian coast.

\section{RESULTS AND DISCUSSION}

One of the problems in determining $R$ from museum samples is that the year of collection can be different from the year of death of the mollusk that formed the shell. No documentation was available to indicate whether the samples used in this study were collected alive or not. To avoid this problem, shells without evidence of abrasion or fading were chosen. The best species for this purpose was $J$. janthina because this gastropod lives floating in the sea (Goffergé 1950) and has a fragile shell that can resist only low transport on the beach. The shell color fades quickly on exposure to sunlight (Figure 2a). In this case, it was considered that the collection date was close to the death date. Furthermore, Goffergé (1950), who collected the dated shell, comments that in Santa Catarina he collected some living specimens floating on the sea. Shells of $R$. plicatella are also fragile and susceptible to damage when transported, so that the collection date can be assumed to be close to the death date (Figure 2b). A specimen of P. morio was also considered favorable for dating because part of the periostracum was preserved (Figure 2c). This organic tissue is rapidly degraded after the organism's death. Another dated sample was a C. maculata shell collected, with no evidence of abrasion, by Goffergé in Ilha do Francês. Goffergé (1950) commented that he collected many live specimens at that place. Although the sample age $(580 \pm 40 \mathrm{BP})$ was older than the other samples, it is compatible with the age of the J. janthina and R. plicatela shells. Some of the museum specimens had cirriped and juvenile oyster shells attached to the inner shell (Figure 2d). These encrustations are evidence of a certain period of time between the date of collection and the date of death.

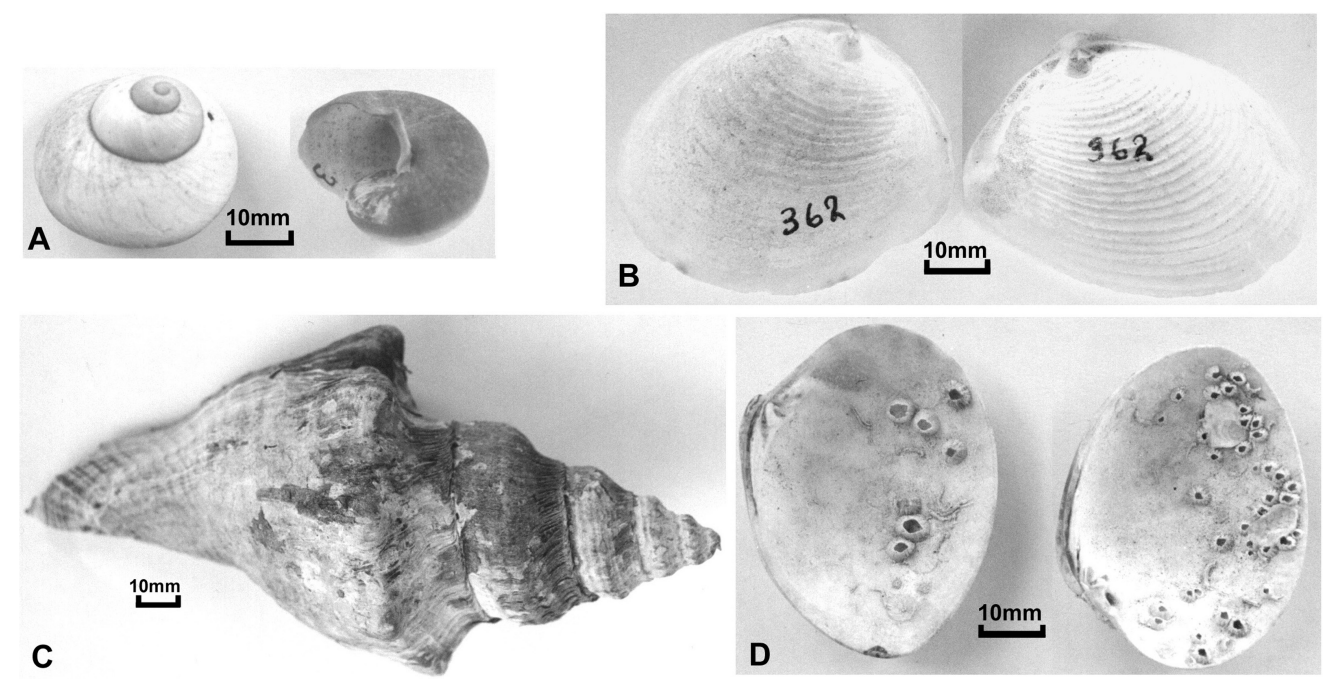

Figure 2 Specimens of dated shell: a) Janthina janthina shell; b) Raeta plicatella shell; c) Pugilina morio shell—the dark parts are preserved periostracum; d) Callista maculata shell with encrustations of cirriped and juvenile oysters. 
To verify the assumed small difference between the collection date and the death of the samples, a sample of cirriped encrusted on a $P$. morio shell was dated. The cirriped age ( $460 \pm 40 \mathrm{BP})$ and that of the P. morio $(410 \pm 40 \mathrm{BP})$ agree within the error of the ${ }^{14} \mathrm{C}$ method. It is possible to conclude that in all cases, both the collection dates and death dates are probably similar.

The 6 samples from this study give conventional ${ }^{14} \mathrm{C}$ ages between $580 \pm 40$ and $410 \pm 40 \mathrm{BP}$, $R$ between $512 \pm 42$ and $345 \pm 42{ }^{14} \mathrm{C}$ yr, and $\Delta \mathrm{R}$ between $112 \pm 41$ and $-55 \pm 41{ }^{14} \mathrm{C}$ yr, with a mean of $33 \pm 24{ }^{14} \mathrm{C}$ yr (Table 1 and Figure 1). Including previously published data for shells of known age in this region (Eastoe et al. 2002; Nadal de Masi 2001), we see the $\Delta \mathrm{R}$ values cluster into 2 groups (Figure 3). One group has a mean value of $8 \pm 17{ }^{14} \mathrm{C}$ yr, while the 3 highest points have a mean value of $219 \pm 26{ }^{14} \mathrm{C}$ yr. The variation in the data could result from seasonal to decadal upwelling of old carbon, as suggested by Eastoe et al. (2002). However, the largest differences are for samples of the same species collected in the same location and year. Short-term differences in upwelling should therefore not be a factor in the $\Delta \mathrm{R}$ variation in these samples, assuming that sampling was fairly homogenous over a growth ring or rings. Although it would seem unlikely that some of the samples in the previous studies could have been several hundred years old at the time of collection, specimens can die, be buried and exhumed before their shells are collected or shells from the inner shelf could be transported to the beach during big storms. This has been observed in shells from museum collections that dated to several thousand years old (Ingram and Southon 1996). Unless the shells are especially fragile, have colors that are light sensitive, or the periostracum is preserved, it is difficult to estimate the time between death and collection. Age differences could also result from differences in local habitat and food sources; however, this is more likely for gastropods that can scrape up old limestone or for deposit feeders as opposed to filter feeders like most pelecypods (Forman and Polyak 1997; Hogg et al. 1998). While we cannot definitely rule out a combination of decadal-scale upwelling and small differences in the collection and death date for the 3 samples with the highest $\Delta \mathrm{R}$ values (Figure 3), the remaining 6 results presented in this work-five published by Nadal de Masi (2001) and one presented by Eastoe et al. (2002) - provide a robust estimate of the regional $R$ of $408 \pm 18{ }^{14} \mathrm{C}$ yr and a $\Delta \mathrm{R}$ value of $8 \pm 17{ }^{14} \mathrm{C}$ yr for the southern and southeastern Brazilian marine surficial coastal waters during the mid-20th century.

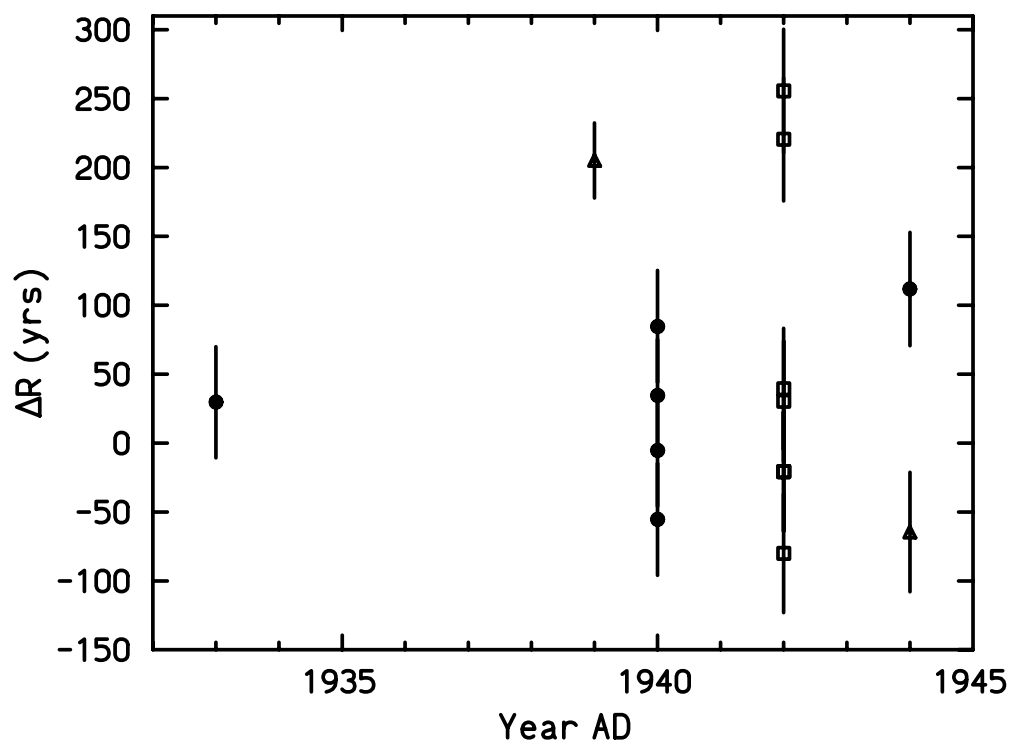

Figure $3 \Delta \mathrm{R}$ values obtained from pre-nuclear testing shells from this study (circles) and previous studies (squares: Nadal de Masi 2001; triangles: Eastoe et al. 2002). 
Regarding longer-scale variation in $R$, the value of $220 \pm 20{ }^{14} \mathrm{C}$ yr obtained by Eastoe et al. (2002) from shell mound samples is subject to influence by fresh continental water. These samples were collected in a shell mound (Jabuticabeira) located beside a paleolagoon with strong fluvial input (Figure 4). Measurements of ${ }^{14} \mathrm{C}$ on 2 shell mound samples, located on the Holocene barrier that closed the Garopaba do Sul lagoon, give ${ }^{14} \mathrm{C}$ ages of $3450 \pm 80$ and $4240 \pm 190$ BP (Martin et al. 1988). These results show that the paleolagoon already existed when the Jabuticabeira shell mound was built (Figure 4). Before the human modifications of the lagoon inlet, Garopaba do Sul lagoon was a blind estuary. At the present time, in spite of structures built to maintain the opening of the inlet, the salt wedge has small penetration (Bonetti Filho et al. 2001). Fluvial input can result in either increased or decreased reservoir corrections depending on whether or not there is a source of carbonate in the watershed (Goodfriend and Flessa 1997; Ulm 2002). In addition, charcoal samples deriving from driftwood or the inner trunk wood of long-living terrestrial plants could reduce the apparent difference between the shell and charcoal ages. These factors would suggest that the $R$ determined from the Jabuticabeira shell mound does not represent the $R$ of coastal marine waters.

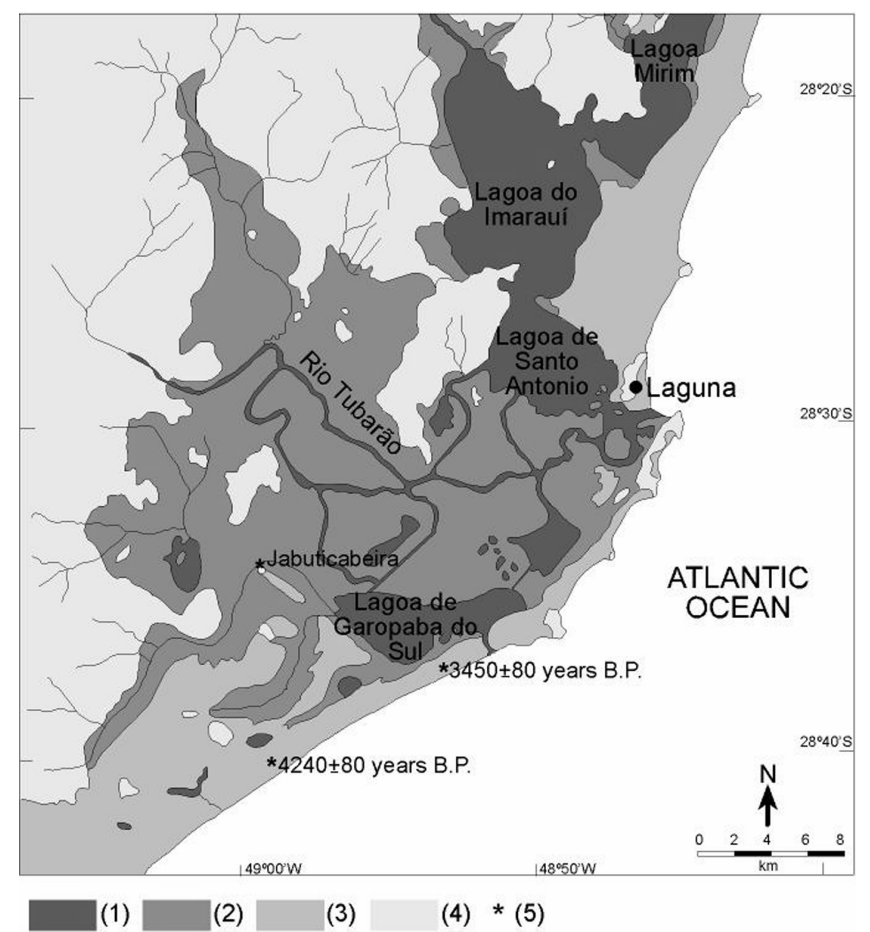

Figure 4 Locality and geology of the Tubarão River mouth region, in Santa Catarina state, southern Brazil, where the Jabuticabeira shell mound is located (after Angulo et al. 1999; dating and shell mound locality after Martin et al. 1988): 1) river, lake, or lagoon; 2) Holocene lagoonal system; 3) Holocene and Pleistocene barriers; 4) other units; 5) shell mound samples' dates.

To improve the regional $R$ estimation, new ${ }^{14} \mathrm{C}$ measurements are necessary. They need to be performed on shells from organisms collected live before the nuclear explosions in the atmosphere. To know the $R$ variation in the Holocene, it would be necessary to date contemporaneous terrestrialmarine samples from marine archeological sites not influenced by continental waters, or to choose 
samples of purely marine origin, like marine shells or fish bone. Using terrestrial samples derived from fruits, seeds, or other short-lived material, where possible, would avoid the problem of longlived terrestrial plants.

\section{ACKNOWLEDGMENTS}

We acknowledge biologists Gilda Maria Siqueira Tebet and Dr Teresa Cristina Castellano Margarido of the Museu de História Natural Capão da Imbuia for their help in obtaining the samples. We thank Jarbas Bonetti Filho, Marco Aurelio Nadal de Masi, and Maria Dulce Gaspar for their information and comments, and especially to Chris J Eastoe for information, comments, and critical review. We also thank CNPq for the scholarships and financial support (process 460134/00-0) and to Fundação Araucária for financial support (project P-451, Ch-001/2000). A portion of this work was performed under the auspices of the US Department of Energy by the University of California, Lawrence Livermore National Laboratory, under Contract No. W-7405-Eng-48.

\section{REFERENCES}

Angulo RJ, Lessa GC. 1997. The Brazilian sea level curves: a critical review with emphasis on the curves from Paranaguá and Cananéia regions. Marine Geology 140:141-66.

Bonetti Filho J, Beltrame JT, Bonetti C, Pereira MLM. 2001. Dinâmica estuarina e transporte sedimentar no eixo Barra de Laguna-Rio Tubarão, SC. In: Congresso da Associação Brasileira de Estudos do Quaternário, 8, Abequa, Mariluz, Imbé. Boletin de Resumos Abequa, Mariluz, Imbé. p 157-8.

Eastoe CJ, Fish P, Dulce Gaspar M, Long A. 2002. Reservoir corrections for marine samples from the South Atlantic coast, Santa Catarina State, Brazil. Radiocarbon 44(1):145-8.

Forman SL, Polyak L. 1997. Radiocarbon content of prebomb marine mollusks and variations in the C-14 reservoir age for coastal areas of the Barents and Kara seas, Russia. Geophysical Research Letters 24:885-8.

Gofferjé CN. 1950. Contribuição à zoogeografia da malacofauna do litoral do Estado do Paraná. Arqueologico Museu Paraná 8:221-82.

Goodfriend GA, Flessa KW. 1997. Radiocarbon reservoir ages in the Gulf of California: roles of upwelling and flow from the Colorado River. Radiocarbon 39(1):139-48.

Hogg AG, Higham TFG, Dahm J. 1998. C-14 dating of modern marine and estuarine shellfish. Radiocarbon 40(2):975-84.

Hogg AG, McCormac FG, Higham TFG, Reimer PJ, Baillie MGL, Palmer J. 2002. High-precision ${ }^{14} \mathrm{C}$ measurements of contemporaneous tree-ring dated wood from the British Isles and New Zealand: AD 1850-950. Radiocarbon 44(3):633-40.
Ingram BL, Southon JR. 1996. Reservoir ages in eastern Pacific coastal and estuarine waters. Radiocarbon 38(3):573-82

Martin L, Suguio K, Flexor JM, Azevedo AEG. 1988. Mapa geológico do Quaternário costeiro dos estados do Paraná e Santa Catarina. Série Geologico DNPM. Brasília, nr 28.2 maps. 40 p.

Nadal de Masi MA. 2001. Pescadores coletores da costa sul do Brasil. Pesquisas Antropologia 57:1-136.

Reimer PJ, Reimer RW. 2001. A marine reservoir correction database and on-line interface. Radiocarbon 43(2A):461-3. URL: <http://www.calib.org/marine>. Accessed 13 June 2003.

Suguio K, Martin L, Bittencourt ACSP, Dominguez JML, Flexor JM, Azevedo AEG de. 1985. Flutuações do nível relativo do mar durante o quaternário superior ao longo do litoral brasileiro e suas implicações na sedimentação costeira. Revista Brasileira de Geociências 15(4):273-86.

Stuiver M, Braziunas TF. 1993. ${ }^{14} \mathrm{C}$ ages of marine samples to 10,000 BC. Radiocarbon 35(1):137-89.

Stuiver M, Pearson GW, Braziunas TF. 1986. Radiocarbon age calibration of marine samples back to 9000 cal years BP. Radiocarbon 28(2B):980-1021.

Stuiver M, Polach HA. 1977. Discussion: reporting of ${ }^{14} \mathrm{C}$ data. Radiocarbon 19(3):355-63.

Stuiver M, Reimer PJ, Braziunas TF. 1998. High-precision radiocarbon age calibration for terrestrial and marine samples. Radiocarbon 40(3):1127-51.

Ulm S. 2002. Marine and estuarine reservoir effects in central Queensland, Australia: determination of $\Delta \mathrm{R}$ values. Geoarchaeology 17:319-48. 